\title{
IPTEKS BAGI MASYARAKAT MAKANAN PENDAMPING ASI (MP ASI) IKAN MUJAIR
}

\author{
${ }^{1)}$ Lilik Hidayanti, ${ }^{2)}$ Sri Maywati \\ 1), 2)Fakultas Ilmu Kesehatan, Universitas Siliwangi \\ 1) email: lilikhidayanti@unsil.ac.id
}

\begin{abstract}
After six months till two years old, children need an adequate of food addition to breast milk so that their nutrition requirement can be fullfilled to prevent the child from growth faltering and disorder of brain development. Tilapia is local foods which it can used to make food addition to breast milk because it has much advantages, such as cheapest of protein animal source, non allergen, easy to be cultivated, growing faster, thick meat and huge. Most people cultivate tilapia in "balong". Several things which it cause tilapia is not used by the people for food addition to breast milk such as 1). People doesn't have knowledge and skill to using tilapia for making food addition to breast milk, 2). People doesn't have knowledge about ingredient of nutritient of tilapia. The purposes of this activities are making client 1). able to make food addition to breast milk, 2). increase intake of energy and protein of client's children and 3). Increase nutrition status of client's children. Subjects of this activities are 30 mothers who have children the age under of two years and they always come to POSYANDU in Sukarame district.
\end{abstract}

Keywords : Children the age under of two years, Food Adition to Breast Milk, Tilapia

\section{PENDAHULUAN}

Setelah bayi berumur 6 bulan sampai dengan dua tahun (baduta), asupan gizinya tidak dapat hanya dipenuhi dari ASI saja. Pada periode ini, baduta membutuhkan asupan makanan lain yaitu Makanan Pendamping ASI (MP ASI). Kandungan gizi di dalam MP ASI harus mampu memenuhi kebutuhan gizi baduta agar tidak terjadi growth faltering (kegagalan pertumbuhan) dan gangguan perkembangan otak. Karena Baduta adalah periode kesempatan emas kehidupan (window of opportunity) dan merupakan periode 1000 Hari Pertama Kehidupan (HPK) yang akan mempengaruhi kualitas hidup manusia di masa-masa yang akan datang. Oleh karena itu, apabila terjadi masalah gizi pada periode ini maka akan berdampak pada kualitas SDM dan akhirnya berdampak pada daya saing bangsa.

Berdasarkan hasil observasi menunjukkan bahwa Kecamatan Sukarame berada di Kabupaten Tasikmalaya yang sudah dikenal sejak lama merupakan sentra produksi perikanan darat di Jawa Barat, salah satunya adalah ikan mujair. Kelebihan ikan mujair antara lain adalah merupakan sumber protein hewani yang murah, budidayanya mudah, pertumbuhannya cepat, memiliki daging yang tebal dan ukuran yang besar. Budidaya ikan mujair biasanya dilakukan di kolam atau dalam bahasa sunda disebut dengan balong. Sebagian besar masyarakat di Kecamatan Sukarame memiliki kolam ikan atau balong ini.

Berlimpahnya produksi perikanan darat ini merupakan sumber protein non alergen yang baik bagi baduta apabila diolah menjadi MP ASI. Pembuatan MP ASI dengan menggunakan bahan pangan lokal seperti ikan mujair mempunyai banyak keuntungan antara lain memiliki harga yang murah sehingga terjangkau, bahan pangan mudah 
didapat, serta merupakan upaya edukasi kepada baduta untuk mengenal berbagai macam rasa dan jenis makanan sehingga anak kelak dapat menyukai makanan yang beraneka ragam yang ada di sekitar mereka. Kegiatan ini bertujuan untuk mengetahui dampak dampak pelatihan pembuatan MP ASI berbahan baku ikan mujair terhadap peningkatan asupan energi dan protein baduta.

\section{METODE PELAKSANAAN}

Sasaran dalam kegiatan ini adalah 30 ibu rumah tangga yang memiliki anak yang berumur di bawah dua tahun (baduta), aktif ke posyandu, memiliki kolam ikan, memiliki peralatan untuk membuat MP ASI ikan mujair. Sasaran dibagi menjadi tiga kelompok yang masing-masing kelompok berjumlah 10 orang dengan satu orang kader sebagai fasilitator. Transfer Ipteks yang dilakukan meliputi tahapan kegiatan ; (1) Somatic : mitra menerima informasi dengan mengalami dan melakukan. Metode yang digunakan pada tahap ini adalah menunjukkan bukti melalui pemantauan asupan makan dan pemantauan berat badan selama baduta mengkonsumsi MP ASI Ikan Mujair ; (2) Auditory: mitra menerima informasi dengan mendengarkan, menyimak, dan menanggapi. Metode yang dilakukan pada tahap ini adalah pelatihan; (3) Visualization : mitra menerima informasi melalui mengamati, demonstrasi, dan penggunaan media atau alat peraga. Metode yang digunakan pada tahap ini adalah demonstrasi pembuatan MP ASI ikan mujair (4) Intellectualy : mitra menerima informasi dengan berlatih dan menerapkan. Metode yang dilakukan pada tahap ini adalah pendampingan penerapan pembuatan MP ASI Ikan Mujair.

\section{HASIL PELAKSANAAN KEGIATAN}

Kegiatan ini dilakukan kepada sasaran yaitu kelompok ibu yang memiliki baduta dan aktif datang ke posyandu.

\section{Karakteristik Sasaran}

Tabel 1 menunjukkan bahwa sebagian besar sasaran dalam kegiatan pengabdian kepada masyarat untuk kegiatan berpendidikan SD, tidak bekerja atau ibu rumah tangga, dan rata-rata umur sasaran adalah 21 tahun.

Tabel 1 Distribusi Frekuensi Pendidikan Sasaran

\begin{tabular}{lcc}
\hline Variabel & n & \% \\
\hline Pendidikan & \multicolumn{2}{c}{} \\
SD & 25 & 83,3 \\
SMP & 2 & 6,7 \\
SMA & 3 & 10,0 \\
\hline Pekerjaan & \multicolumn{2}{c}{} \\
Tidak Bekerja & 29 & 96,7 \\
Bekerja & 1 & 3,3 \\
\hline Nilai Statistik & \multicolumn{3}{c}{ Umur (tahun) } \\
\hline Rata-rata & 21 & \\
Standar Deviasi & 11,4 & \\
Minimal & 16 & \\
Maksimal & 33 & \\
\hline
\end{tabular}

Pelaksanaan IbM MP ASI Ikan Mujair dilakukan dengan kegiatan sebagai berikut;

1. Sosialisasi kegiatan

Sebelum dilakukan pelaksanaan kegiatan maka terlebih dahulu dilakukan sosialisi terkait dengan kegiatan yang akan dilaksanakan, tujuan, lokasi, materi kegiatan, waktu, sasaran dan fasilitator kegiatan.

Sosialisasi dilakukan kepada pemangku kebijakan yang ada di wilayah Kecamatan Sukarame, antara lain pihak Puskemas Sukarame, desa serta ketua Posyandu Batugugur dan Sukamanah

2. Pembagian Kelompok

Pembagian kelompok dilakukan setelah terlebih dahulu berdiskusi dengan kader posyandu. Kelompok dibagi menjadi tiga yang masing-masing anggota berjumlah sepuluh orang dengan satu kader menjadi fasilitator atau pendampingnya.

3. Pelaksanaan Kegiatan

Kegiatan dilakukan meliputi tiga tahapan, yaitu :

\section{Tahap pertama}

Kegiatan pada tahap pertama adalah Promosi MPASI Ikan Mujair dan Demontrasi pembuatan MP ASI Ikan Mujair serta 
analisis kandungan zat gizinya. Kegiatan ini bertujuan untuk memberikan pengetahuan dan pemahaman kepada mitra mengenai cara pembuatan MP ASI Ikan Mujair sehingga mitra menjadi tahu cara membuat MP ASI Ikan Mujair dengan benar.
Kegiatan dilaksanakan pada tanggal 6 Februari 2017 bertempat di salah satu rumah warga. Setelah kegiatan promosi maka dilanjutkan dengan demonstrasi pembuatan MP ASI berbahan baku ikan mujair yang disampaikan oleh ketua tim IbM.

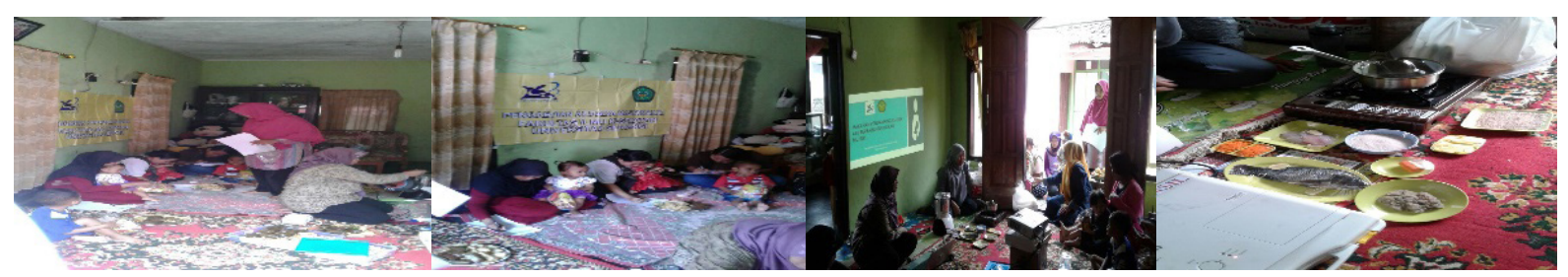

Gambar 1. Kegiatan Promosi MP ASI Ikan Mujair

\section{Tahap Kedua}

Kegiatan pada tahap kedua adalah Pelatihan dan pendampingan yang bertujuan memberikan ketrampilan kepada mitra mengenai cara pembuatan MP ASI Ikan Mujair sehingga mitra mampu membuat MP ASI Ikan Mujair secara mandiri.

\section{Kegiatan Pelatihan}

Kegiatan pelatihan yang dilakukan meliputi : a). Refreshing b). Latihan secara mandiri. Kegiatan pelatihan dilakukan pada tanggal 18 Maret 2017 mulai dari jam 08.00 WIB sampai dengan jam 16.00 WIB dengan sasaran sebanyak 30 orang. Sasaran berlatih secara berkelompok dan setiap kelompok jumlah sasaran sebanyak 10 orang dengan satu orang pendamping. Setiap kelompok disediakan bahan dan peralatan untuk membuat MP ASI berbahan ikan mujair. Waktu disediakan per kelompok selama 3 jam. Pada pelatihan ini setiap anggota kelompok diwajibkan mencoba membuat MP ASI

\section{Kegiatan Pendampingan}

Setelah kegiatan pelatihan maka pada bulan april dilakukan kegiatan pendampingan untuk maka semua sasaran. Setiap sasaran mendapatkan pendampingan pembuatan MP ASI berbahan baku Ikan Mujair saat mereka mencoba membuat sendiri secara mandiri di rumah masing-masing. Bahan dan peralatan yang digunakan membuat MP ASI adalah milik masing-masing sasaran. Pendampingan dilakukan secara langsung oleh ketiga fasilitator yang memang tinggal berdekatan dengan sasaran.

Pelaksanaan pendampingan dilakukan sebanyak satu kali untuk masing-masing sasaran. Waktu yang dibutuhkan untuk pelaksanaan pendampingan selama 5 hari. Dalam satu hari fasilitator akan mendampingi 2 orang sasaran dengan jadwal pagi dan sore hari. Pendampingan dilakukan dengan cara fasilitator mendatangi rumah sasaran sesuai dengan waktu yang telah ditentukan.

\section{Tahap ketiga}

Kegiatan pada tahap ketiga adalah Pemantauan kejadian kecacingan selama baduta mengkonsumsi MP ASI Ikan Mujair dengan metode eosin, Pemantauan asupan MP ASI Ikan Mujair pada baduta dengan metode visual comstock, dan Pemantauan berat badan baduta selama mengkonsumsi MP ASI Ikan Mujair dengan metode antropometri. Kegiatan ini bertujuan agar mitra bersikap atau berpersepsi baik sehingga mau mengadopsi dan memberikan MP ASI Ikan Mujair kepada baduta nya.

\section{Pemantauan kejadian kecacingan}

Pemantauan kejadian kecacingan dilakukan sebanyak 2 kali. Pengambilan sampel feses yang pertama dilakukan pada tanggal 12 Februari 2017 atau tepat sehari setelah pemberian promosi dan demonstrasi pembuatan MP ASI Ikan mujair. Pada saat dilakukan pemantauan kejadian kecacingan yang pertama diasumsikan bahwa sasaran belum memberikan MP ASI Ikan Mujair 
kepada Badutanya atau dianggap sebagai kondisi awal. Sedangkan pengambilan sampel feses kedua dilakukan pada tanggal 19 Maret 2017 atau satu bulan setelah promosi dan demonstrasi dilakukan. Tempat pemeriksaan dilakukan di laboratorium kesehatan daerah (Lab Kesda) Kabupaten Tasikmalaya dengan sampel seluruh baduta sasaran yang berjumlah 30 .

Tabel 2. Kejadian Kecacingan Sebelum dan Sesudah Pemberian MP ASI Ikan Mujair

\begin{tabular}{lccccccc}
\hline \multirow{2}{*}{ Pemberian MP ASI ikan mujair } & \multicolumn{3}{c}{ Kejadian kecacingan } & \multicolumn{2}{c}{ Total } \\
\cline { 2 - 6 } & \multicolumn{2}{c}{ Positif } & \multicolumn{2}{c}{ Negatif } & & \\
\cline { 2 - 6 } & $\mathrm{n}$ & $\%$ & $\mathrm{n}$ & $\%$ & $\mathrm{n}$ & $\%$ \\
\hline Sebelum pemberian & 1 & 33,3 & 29 & 96,7 & 30 & 100,0 \\
Sesudah pemberian & 0 & 0,0 & 30 & 100,0 & 30 & 100,0 \\
\hline
\end{tabular}

Hasil pemantauan kejadian kecacingan menunjukkan bahwa pada pemeriksaan yang pertama diketahui ada satu orang baduta sasaran yang dinyatakan positif karena ditemukan adanya cacing tambang pada pemeriksaan eosin. Pada pemeriksaan yang kedua tidak ditemukan baduta yang mengalami kecacingan. Hasil ini menunjukkan bahwa pemberian ikan mujair pada baduta tidak menyebabkan terjadinya kecacingan.

\section{Pemantauan asupan MP ASI ikan mujair}

Pemantauan asupan MP ASI Ikan Mujair pada baduta dilakukan dengan menggunakan metode visual comstock. Hasil pengukuran taksiran visual Comstock menunjukkan bahwa pada pengukuran pertama (februarimaret) rata-rata MP ASI Berbahan Ikan Mujair yang dihabiskan sebanyak 61,45 $\%$, pada pengukuran kedua (maret-april) meningkat menjadi $63,88 \%$ dan pada bulan ketiga (april-mei) menjadi 67,5\%.

Tabel 3. Penghitungan Nilai Statistik Hasil Taksiran Visual Comstock Asupan MP ASI Ikan Mujair

\begin{tabular}{|c|c|c|c|c|c|c|c|c|c|c|c|c|}
\hline \multirow[t]{2}{*}{ Kelompok } & \multicolumn{4}{|c|}{$\begin{array}{c}1 \\
\text { (\%/bulan) }\end{array}$} & \multicolumn{4}{|c|}{$\begin{array}{c}2 \\
\text { (\%/bulan) }\end{array}$} & \multicolumn{4}{|c|}{$\begin{array}{c}3 \\
\text { (\%/bulan) }\end{array}$} \\
\hline & Mean & SD & Min & Max & Mean & SD & Min & Max & Mean & SD & Min & Max \\
\hline Kelompok 1 & 75 & 21,6 & 50 & 100 & 72,5 & 21,8 & 50 & 100 & 75,0 & 20,4 & 50 & 100 \\
\hline Kelompok 2 & 53,57 & 17,25 & 25 & 75 & 63,8 & 28,25 & 25 & 100 & 72,5 & 24,86 & 25 & 100 \\
\hline Kelompok 3 & 53,12 & 20,86 & 25 & 100 & 53,12 & 20,86 & 25 & 100 & 55,00 & 19,72 & 25 & 100 \\
\hline Total & 61,45 & 22,09 & 25 & 100 & 63,88 & 24,35 & 25 & 100 & 67,50 & 22,88 & 25 & 100 \\
\hline
\end{tabular}

Pola kegiatan yang dilakukan menunjukkan adanya kemampuan dan kemauan dari sasaran untuk membuat dan memberikan MP ASI Ikan Mujair kepada badutanya. Kegiatan yang dilakukan menyasar semua indera sasaran sehingga diharapkan hasil dari kegiatan ini dapat bertahan lama dan masyarakat mampu memanfaatkan keberadaan ikan mujair sebagai sumber protein hewani yang non allergen untuk anak mereka.

Tabel 4. Distribusi Frekuensi Hasil Pengukuran Taksiran Visual Comstock

\begin{tabular}{ccccccccc}
\hline \multirow{2}{*}{$\begin{array}{c}\text { Prosentase MP ASI } \\
\text { ikan mujair yang } \\
\text { dihabiskan }\end{array}$} & Kelompok & \multicolumn{6}{c}{ Pengukuran Ke- } \\
\cline { 3 - 8 } & & & $\mathbf{1}$ & & & $\mathbf{2}$ & & $\mathbf{3}$ \\
\hline $100 \%$ & 1 & 3 & 75,0 & 3 & 50,0 & 3 & 42,8 \\
& 2 & 0 & 0,0 & 2 & 33,3 & 3 & 42,8
\end{tabular}




\begin{tabular}{lccccccc} 
Jumlah & 3 & 1 & 25,0 & 1 & 16,7 & 1 & 14,4 \\
\hline $75 \%$ & & $\mathbf{4}$ & $\mathbf{1 6 , 6}$ & $\mathbf{6}$ & $\mathbf{2 2 , 2}$ & $\mathbf{7}$ & $\mathbf{2 3 , 3}$ \\
& 2 & 3 & 60,0 & 3 & 50,0 & 4 & 44,4 \\
Jumlah & 2 & 40,0 & 3 & 50,0 & 4 & 44,4 \\
\hline $50 \%$ & & 0 & 0,0 & 0 & 0,0 & 1 & 11.2 \\
& 1 & $\mathbf{5}$ & $\mathbf{2 0 . 8}$ & $\mathbf{6}$ & $\mathbf{2 2 , 2}$ & $\mathbf{9}$ & $\mathbf{3 0 , 0}$ \\
\hline Jumlah & 2 & 4 & 23,07 & 4 & 33,4 & 3 & 25,0 \\
\hline $25 \%$ & 3 & 6 & 46,15 & 6 & 50,0 & 7 & 58,4 \\
& & $\mathbf{1 3}$ & $\mathbf{5 4 , 2}$ & $\mathbf{1 2}$ & $\mathbf{4 4 , 4}$ & $\mathbf{1 2}$ & $\mathbf{4 0 , 0}$ \\
\hline Jumlah & 1 & 0 & 0,0 & 0 & 0,0 & 0 & 0,0 \\
\hline $0 \%$ & 2 & 1 & 50,0 & 2 & 66,6 & 1 & 50,0 \\
& 3 & 1 & 50,0 & 1 & 33,4 & 1 & 50,0 \\
& & $\mathbf{2}$ & $\mathbf{8 , 4}$ & $\mathbf{3}$ & $\mathbf{1 1 , 2}$ & $\mathbf{2}$ & $\mathbf{6 , 7}$ \\
\hline Jumlah & 1 & 0 & 0,0 & 0 & 0,0 & 0 & 0,0 \\
\hline Total & 2 & 0 & 0,0 & 0 & 0,0 & 0 & 0,0 \\
\hline
\end{tabular}

Pada pengukuran pertama dari 24 sasaran yang memberikan MP ASI Ikan Mujair untuk baduta, hasil pengukuran taksiran visual comstock menunjukkan bahwa separuh $(54,2 \%)$ baduta sasaran menghabiskan $50 \%$ MP ASI yang diberikan. Pada pengukuran pertama juga diketahui bahwa ada 16,6 \% baduta yang menghabiskan MP ASI ikan mujair 100\% atau mampu menghabiskan seluruh MP ASI yang diberikan. Pada pengukuran kedua jumlah baduta yang mampu menghabiskan MP ASI $100 \%$ meningkat menjadi 22,2 \% dan pada pengukuran ketiga naik menjadi $23,3 \%$.

\section{Pemantauan Berat Badan}

Pemantauan berat badan baduta selama mengkonsumsi MP ASI Ikan Mujair dengan metode antropometri. Kegiatan ini bertujuan agar mitra bersikap atau berpersepsi baik sehingga mau mengadopsi dan memberikan MP ASI Ikan Mujair kepada baduta nya.

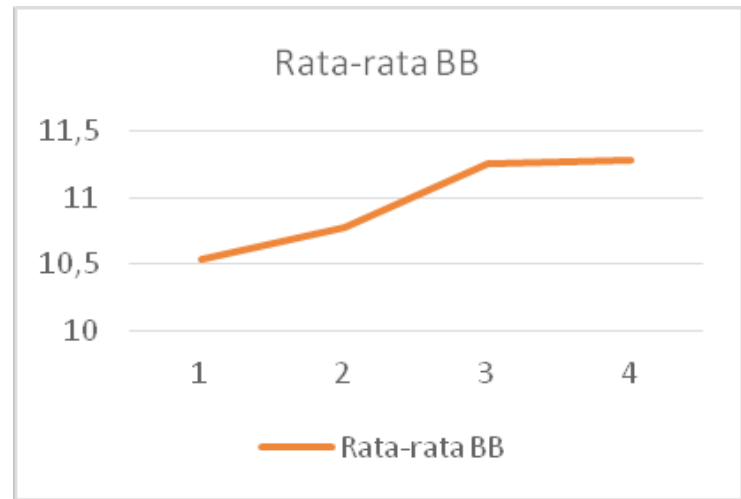

Grafik 1. Rata-rata berat badan baduta selama kegiatan dilaksanakan

Keterangan:

Bulan ke-1 : BB sebelum kegiatan

Bulan ke-2 : BB pada bulan pertama

Bulan ke 3 : BB pada bulan ke dua

Bulan ke 4 : berat badan pada bulan ke tiga

Hasil pemantauan berat badan baduta yang dilakukan selama tiga bulan menunjukkan bahwa ada peningkatan ratarata berat badan baduta.

\section{Evaluasi Kegiatan}

Evaluasi kegiatan merupakan tahapan keempat dari pelaksanaan kegiatan PPM. Evaluasi dilakukan untuk mengetahui 
keberhasilan kegiatan yang sudah dilakukan dengan cara:

1. Evaluasi pemahaman sasaran mengenai pembuatan MP ASI ikan mujair

Untuk mengevaluasi bahwa mitra tahu cara pembuatan MP ASI Ikan Mujair dengan baik dilakukan dengan membandingkan pengetahuan mitra sebelum dan sesudah menerima kegiatan promosi dan demontrasi melalui pre test dan post test. Untuk mengetahui perbedaan hasil pre test dan post test digunakan analisis pair sample t test.

Hasil pre test menunjukkan bahwa masih ada sasaran yang menyatakan anak berumur di bawah dua tahun tidak diperbolehkan mengkonsumsi ikan mujair (53,3\%). Setelah dilakukan promosi serta demonstrasi pembuatan MPASI ikan Mujair menunjukkan bahwa pada hasil post test semua sasaran menyatakan anak yang berumur di bawah dua tahun boleh diperbolehkan mengkonsumsi ikan mujair.

Pada hasil pre test juga menunjukkan bahwa pemberian ikan mujair pada anak yang berumur di bawah dua tahun dapat menyebabkan alergi $(20,0 \%)$ dan kecacingan $(16,7 \%)$, namun pada hasil post test menunjukkan tidak ada (0\%) sasaran yang menyatakan ikan mujair dapat menyebabkan alergi dan hanya $1(3,3 \%)$ sasaran yang masih menyatakan bahwa ikan mujair dapat menyebabkan terjadinya kecacingan.

Hasil pre test menunjukkan bahwa masih ada sasaran yang menyatakan anak berumur di bawah dua tahun tidak diperbolehkan mengkonsumsi ikan mujair (53,3\%). Setelah dilakukan promosi serta demonstrasi pembuatan MPASI ikan Mujair menunjukkan bahwa pada hasil post test semua sasaran menyatakan anak yang berumur di bawah dua tahun boleh diperbolehkan mengkonsumsi ikan mujair.

Pada hasil pre test juga menunjukkan bahwa pemberian ikan mujair pada anak yang berumur di bawah dua tahun dapat menyebabkan alergi $(20,0 \%)$ dan kecacingan $(16,7 \%)$, namun pada hasil post test menunjukkan tidak ada (0\%) sasaran yang menyatakan ikan mujair dapat menyebabkan alergi dan hanya $1(3,3 \%)$ sasaran yang masih menyatakan bahwa ikan mujair dapat menyebabkan terjadinya kecacingan.

Promosi kesehatan dapat diartikan sebagai upaya yang dilakukan terhadap masyarakat sehingga mau dan mampu untuk memelihara dan meningkatkan kesehatan. Salah satu upaya promosi kesehatan dalam bidang gizi khususnya untuk meningkatkan pengetahuan ibu dalam memberikan asupan makanan bergizi kepada anaknya dapat dilakukan dengan memberikan informasi bersamaan dengan kegiatan posyandu melalui pendidikan dan penyuluhan kesehatan.

Penyuluhan kesehatan merupakan suatu kegiatan pemberian informasi tentang hidup sehat untuk mengubah perilaku masyarakat. Penyuluhan kesehatan juga merupakan salah satu bentuk intervensi yang mandiri untuk membantu klien baik individu, keluarga, kelompok maupun masyarakat dalam mengatasi masalah kesehatannya (Fitriani, 2015). Salah satu strategi untuk memperoleh perubahan perilaku menurut WHO adalah dengan pemberian informasi sehingga menimbulkan kesadaran. Metode yang dapat digunakan dapat berupa ceramah dan tanya menjawab yang efektif untuk keperluan penyampaian informasi

Tabel 5. Hasil Skor Pre Test dan Post Test

\begin{tabular}{ccccc}
\hline \multicolumn{1}{c}{ Skor } & $\begin{array}{c}\text { Rata- } \\
\text { rata }\end{array}$ & SD & Min & Maks \\
\hline Sebelum promosi & 22,7 & 2,0 & 19 & 26 \\
Setelah promosi & 27,0 & 0,6 & 25 & 28 \\
\hline
\end{tabular}

Rentang skor pre test antara 19 sampai dengan 26 lebih rendah dibandingkan rentang skor post test yang berkisar antara 25 sampai 28. Rata-rata skor post test juga lebih tinggi dibandingkan dengan rata-rata skor pre test. 


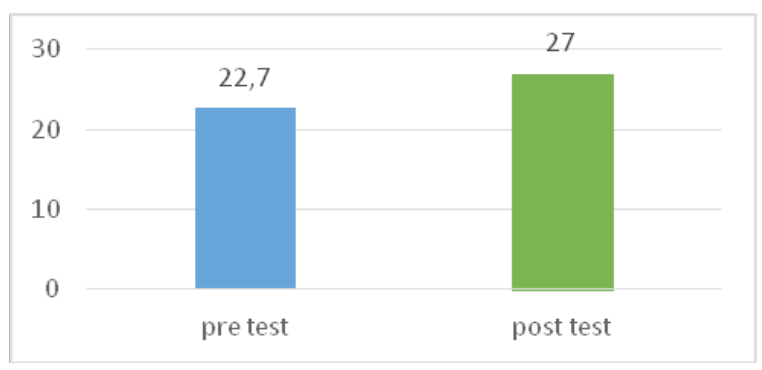

Gambar 2. Grafik Perbedaan Rata-rata skor pre test dan post test

Perbedaan skor pre test dan post test untuk mengevaluasi hasil promosi menggunakan uji Wilcoxon karena data post test tidak berdistribusi normal ( $p$ Value 0,00). Hasil uji Wilcoxon menunjukkan bahwa pValue sebesar 0,00 yang berarti ada perbedaan antara kemampuan sasaran terkait dengan ikan mujair sebelum dilakukan promosi dan sesudah dilakukan promosi. Pada kegiatan ini promosi dilakukan dengan metode ceramah yang menggunakan media slide. Pada kegiatan ini sasaran juga menerima buku saku sebagai sumber belajar di rumah yang dapat dibaca berulang-ulang.

Keberhasilan pendidikan kesehatan ini juga tidak lepas dari pemilihan metode dan media yang tepat. Materi yang diberikan dengan ceramah dengan menggunakan media slide terlihat dapat meningkatkan menarik perhatian sasaran. Slide umumnya digunakan pada sasaran yang berada di suatu ruangan secara berkelompok. Penggunaan slide cukup efektif karena gambar atau materi dapat dilihat berkali-kali dan dibahas lebih mendalam. Slide sangat menarik, terutama bagi kelompok ibu-ibu dibandingkan gambar-gambar dalam buku.

Mubarak (2007), bahwa hasil dan bukti belajar adanya perubahan tingkah laku pada seseorang tersebut, misalnya dari tidak tahu menjadi tahu, dari tidak mengerti menjadi mengerti. Menurut Rapiasih, dkk (2010) pancaindra menentukan berapa banyak informasi yang diserap jika melibatkan mata, telinga disertai diskusi dan latihan, dimana informasi yang diserap bisa mencapai 90\%. Penelitian Zulkarnian, Yusi, Farida (2011), membuktikan pengaruh ada perbedaan pengetahuan tentang IMD sebelum dan sesudah diberikan penyuluhan dengan ceramah.

Hasil Penelitian Bertalina (2015) menununjukkan bahwa hasil uji statistic didapat nilai $\mathrm{P}$ value 0,000 maka dapat disimpulkan ada perbedaan yang signifikan antara nilai pengetahuan pada pengukuran pertama dan kedua yaitu pengukuran sebelum dan sesudah intervensi dengan ceramah dengan media slide. Hasil penelitian ini sama dengan hasil penelitian Wibowo dan Suryani (2013) di Yogyakarta, terdapat perbedaan yang signifikan pengetahuan antara kelompok ibu yang mendapat promosi kesehatan dengan kelompok ibu yang tidak mendapat promosi kesehatan, pada penelitian ini promosi kesehatan dilakukan dengan menggunakan buku saku $(p=0.000)$. Penelitian Meifly S. Moningka1, Anita Lontaan, Robin Dompas (2013) juga menunjukkan bahwa ada pengaruh promosi kesehatan terhadap peningkatan pengetahuan orang tua balita tentang Posyandu di Kelurahan Pinokalan Kecamatan Ranowulu Kota Bitun dengan $\mathrm{p}$ Value 0,004

2. Evaluasi kemampuan mitra dalam membuat MP ASI ikan mujair

Untuk mengetahui bahwa sasaran telah mampu membuat MP ASI berbahan ikan mujair dilakukan dengan dua cara yaitu penilaian atau eveluasi hasil pelatian dan hasil pendampingan.

a. Evaluasi hasil pelatihan

Evaluasi hasil pelatihan dilakukan pada akhir sesi pelatihan dengan cara unjuk kemampuan oleh perwakilan masingmasing kelompok. Setiap kelompok menunjuk satu orang perwakilannya untuk melakukan demontrasi pembuatan MP ASI Ikan Mujair di depan semua sasaran dengan didampingi oleh fasilitatornya masing-masing. Kemudian tim IbM melakukan penilaian terhadap kemampuan peserta. 

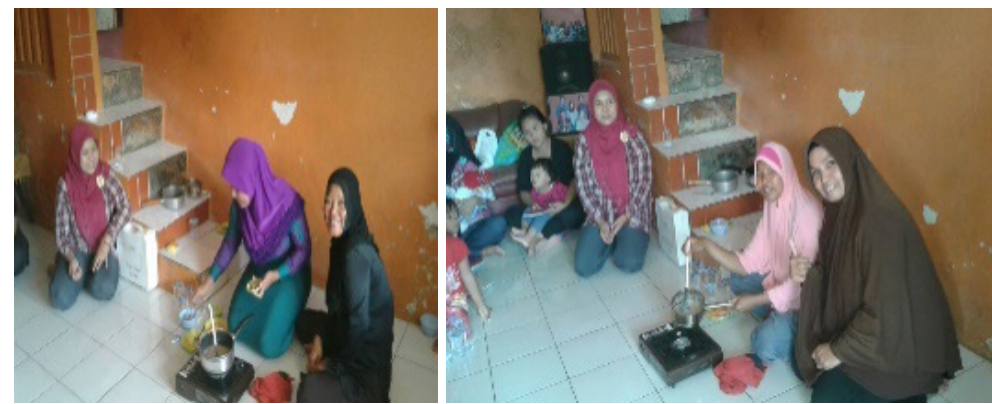

Gambar 2. Unjuk kemampuan pembuatan MP ASI Ikan Mujair setelah pelatihan

Hasil penilaian dari tim IbM menyatakan bahwa masing-masing perwakilan dari tiap kelompok telah mampu mendemonstrasikan pembuatan MP ASI ikan mujair dengan baik.

b. Evaluasi hasil pendampingan

Untuk mengetahui bahwa mitra mampu membuat MP ASI juga dilakukan dengan cara menilai kemampuan mitra secara mandiri membuat MP ASI Ikan melalui home visit. Home visit dilakukan setelah kegiatan pendampingan selesai. Tim IbM melakukan penilaian kepada 3 sasaran yang ditunjuk secara acak untuk mewakili masing-masing kelompok. Hasil penilaian tim IbM menunjukkan bahwa ketiga sasaran telah mampu membuat MP ASI berbahan ikan mujair dengan baik.

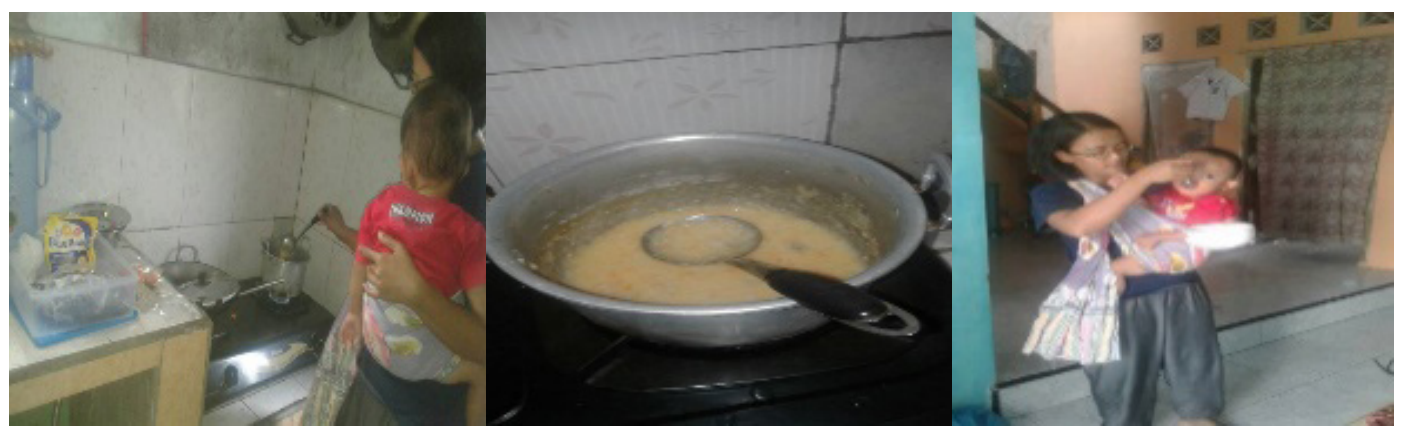

Gambar 3. Unjuk kemampuan secara mandiri setelah pendampingan

Hasil penilaian dari tim IbM terhadap kemampuan 3 orang sasaran yang terpilih juga menunjukkan bahwa ketiga nya telah mampu membuat MP ASI berbahan ikan mujair dengan baik.

3. Evaluasi adopsi program

Untuk mengetahui bahwa mitra mau mengadopsi program kegiatan IbM MP ASI Ikan Mujair dilakukan dengan menilai dampak dari program salah satunya dengan cara menghitung berapa kali ibu mau memberikan MP ASI Ikan Mujair kepada badutanya. Pada saat sebelum dilakukan kegiatan ini, semua sasaran menyatakan belum pernah memberikan MP ASI berbahan baku ikan mujair yang mereka buat sendiri maupun berasal dari tempat lain kepada badutanya.
Kegiatan ini dilakukan dengan cara :

a. Menghitung frekuensi pemberian MP ASI ikan mujair selama satu bulan (kali/ bulan) antara pertengahan bulan februari sampai dengan bulan maret atau setelah kegiatan promosi dan demonstrasi selesai dilakukan.

b. Menghitung frekuensi pemberian MP ASI ikan mujair selama satu bulan (kali/bulan) antara pertengahan bulan maret sampai dengan pertengahan bulan april setelah kegiatan pelatihan dilakukan

c. Menghitung frekuensi pemberian MP ASI ikan mujair selama satu bulan (kali/ bulan) antara pertengahan bulan april sampai dengan pertengahan Mei Setelah pendampingan dan semua kegiatan 
Pengabdian kepada Masyarakat selesai dilakukan.

Hasil kegiatan menunjukkan bahwa setelah dilakukan kegiatan promosi dan demonstrasi jumlah sasaran yang memberikan MP ASI ikan mujair kepada badutanya sebanyak 24 orang $(80,0 \%)$.
Setelah dilakukan kegiatan pelatihan jumlah sasaran yang memberikan MP ASI Ikan Mujair kepada badutanya meningkat menjadi 90,0 \% dan setelah dilakukan pendampingan meningkat menjadi seluruh (100\%) sasaran telah memberikan MP ASI Ikan Mujair kepada badutanya.

Tabel 6. Penghitungan Nilai Statistik Jumlah Pemberian MP ASI Per Bulan Selama

\begin{tabular}{|c|c|c|c|c|c|c|c|c|c|c|c|c|}
\hline \multirow{3}{*}{ Kelompok } & \multicolumn{12}{|c|}{$\begin{array}{l}\text { Jumlah pemberian MP ASI Berbahan Ikan Mujair selama } 1 \text { bulan pada } \\
\text { Pengukuran ke- }\end{array}$} \\
\hline & \multicolumn{4}{|c|}{1} & \multicolumn{4}{|c|}{2} & \multicolumn{4}{|c|}{3} \\
\hline & Mean & SD & Min & Maks & Mean & $\mathrm{SD}$ & Min & Maks & Mean & SD & Min & maks \\
\hline Kelompok 1 & 1,5 & 0,5 & 1 & 2 & 4,4 & 1,5 & 1 & 6 & 5,5 & 1,1 & 3 & 7 \\
\hline Kelompok 2 & 1,85 & 1,06 & 1 & 4 & 4,0 & 1,5 & 1 & 5 & 4,7 & 1,1 & 3 & 7 \\
\hline Kelompok 3 & 1,25 & 0,4 & 1 & 2 & 3,87 & 0,8 & 3 & 5 & 4,6 & 1,7 & 3 & 7 \\
\hline Total & 1,54 & 0,72 & 1 & 4 & 4,11 & 1,3 & 1 & 6 & 4,93 & 1,1 & 3 & 7 \\
\hline
\end{tabular}

Pada pengukuran pertama setelah dilakukan promosi dan demonstrasi, pemberian MP ASI ikan mujair kepada baduta yang dilakukan oleh sasaran berkisar antara 1 sampai dengan 4 kali selama satu bulan, dengan rata-rata sebanyak 1,54 kali per bulan. Pada pengukuran kedua rata-rata pemberian meningkat menjadi 4,11 kali per bulan dan pada pengukuran ketiga menjadi 4,93 kali per bulan.

\section{KESIMPULAN}

Kesimpulan dalam kegiatan promosi ASI ini adalah terdapat peningkatan pemahaman sasaran berdasarkan peningkatan skor sebelum kegiatan dilakukan dan sesudahnya.

\section{SARAN}

Berdasarkan hasil kegiatan yang telah dilakukan maka disarankan unuk melaksanakan kegiatan ini secara kontiyu secara mandiri di bawah bimbingan tenaga kesehatan di Puskesmas dan di bawah koordinasi kader.

\section{UCAPAN TERIMA KASIH}

Pelaksanaan kegiatan ini tidak terlepas dari keterlibatan beberapa pihak. Oleh karena itu, kami menghaturkan terima kasih kepada Kemenristek Dikti melalui DRPM dan LP2M-PMP UNSIL yang telah memberikan bantuan pendanaan sehingga kegiatan ini dapat berjalan dengan baik. Kami juga mengucapkan terima kasih kepada Kepala Puskesmas Sukarame, Kepala Desa Sukarame, Koordinatorosyandu Eldeweis dan Sukarapih, serta seluruh sasaran kegiatan yang telah banyak membantu sehingga kegiatan ini dapat berjalan dengan baik.

\section{DAFTAR PUSTAKA}

BAPPENAS. (2011). RANPG - Rencana Aksi Nasional Pangan dan Gizi 2011-2015. BAPPENAS: Jakarta

Kemenkes RI.(2010). Pedoman Kader Seri Kesehatan Anak. Kemenkes RI: Jakarta

Kemenkes. (2014). Hasil Riskesdas 2013. Kemenkes RI: Jakarta

Lilik Hidayanti \& Sri Maywati. (2014). Ketahanan Pangan (Food Security) Dan Status Gizi 
p ISSN: 1410-9344, e ISSN: 2549-5631

Balita Keluarga Miskin Di Kecamatan Sukarame Kabupaten Tasikmalaya. Laporan Penelitian Dosen Madya Universitas Siliwangi

Lilik Hidayanti \& Sri Maywati. (2015). Ketahanan Pangan Keluarga Miskin yang Memiliki Balita Gizi Kurang di Wilayah Pedesaan dan Perkotaan. Laporan Penelitian Dosen Pemula Meyliana, dkk. (2013). Potensi Budidaya Ikan Mujair: Studi Kasus di Kecamatan Leuwisari Tasikmalaya, Laporan Penelitian Universitas Maranantha: Bandung

Puskesmas Sukarame. (2014). Laporan Tahunan Puskesmas Sukarame, Puskesmas Sukarame

Sri Maywati \& Lilik Hidayanti. (2014). Upaya Meningkatkan Ketahanan Pangan (Food Security) Keluarga Yang Memiliki Balita Kekurangan Gizi Dengan Promosi Konsumsi Makanan Beragam Berbasis Sumber Daya Lokal Melalui Konseling Gizi. Laporan Penelitian Dosen Pemula. 